Article

\title{
Enrichment of Li-Ga-Zr-Hf and Se-Mo-Cr-V-As-Pb Assemblages in the No. 11 Superhigh Organic Sulfur Coal from the Sangshuping Coal Mine, Weibei Coalfield, Shaanxi, North China
}

\author{
Jing Li ${ }^{1} * \mathbb{C}$, Peng $\mathrm{Wu}^{1}{ }^{1}$, Guanghua Yang ${ }^{2}$, Lei Pan ${ }^{2}$, Xinguo Zhuang ${ }^{1}$, Xavier Querol ${ }^{3}$, \\ Natalia Moreno ${ }^{3}{ }^{-}$, Baoqing $\mathrm{Li}^{1}$ and Yunfei Shangguan ${ }^{1}$ \\ 1 Key Laboratory of Tectonics and Petroleum Resources (China University of Geosciences), \\ Ministry of Education, Lumo Road 388, Wuhan 430074, China; pengwu@cug.edu.cn (P.W.); \\ xgzhuang@cug.edu.cn (X.Z.); libq@cug.edu.cn (B.L.); Sgyunfei@cug.edu.cn (Y.S.) \\ 2 Xi'an Institute of Geology and Mineral Exploration, Western Duling Road 56, Xi'an 710100, China; \\ Fushiaihua1999@sina.com (G.Y.); panlei@snjwx.com (L.P.) \\ 3 Institute of Environmental Assessment and Water Research, CSIC, C/Jordi Girona 18-26, \\ 08034 Barcelona, Spain; xavier.querol@idaea.csic.es (X.Q.); natalia.moreno@idaea.csic.es (N.M.) \\ * Correspondence: jingli@cug.edu.cn
}

Received: 14 November 2020; Accepted: 13 December 2020; Published: 17 December 2020

\begin{abstract}
Superhigh organic sulfur(SHOS) coals have currently attracted great attention due to their typical depositional environments and formation history as well as their great negative impact on the ecosystem. This study investigated the geochemistry of the No. 11coalof the Late Carboniferous Taiyuan Formation from the Sangshuping coalmine, Hancheng miningarea, Weibei coalfield, Shaanxi, North China. The No. 11 coal is a high-sulfur coal with a large proportion of organic sulfur content ( 3.7 to $5.5 \%$, avg. $4.4 \%$ ) and belongs to typical SHOS coal. The high sulfur content in the Sangshuping coal mine has been mainly caused by the combined influences of seawater and hydrothermal fluids. The SHOS in No. 11 coal was formed in the Fe-poor and S-rich high-marine influenced occlusive environment. During the late coalification stage, a high proportion of pyritic sulfur was formed due to sufficient Fe supply from the Fe-S-rich epigenetic hydrothermal fluids. The No. 11 SHOS coal is enriched in $\mathrm{Li}-\mathrm{Ga}-\mathrm{Zr}-\mathrm{Hf}$ and $\mathrm{Se}-\mathrm{Mo}-\mathrm{Cr}-\mathrm{V}-\mathrm{As}-\mathrm{Pb}$ element assemblages. The sediment provenance of the Sangshuping coal mine is predominantly felsic-intermediate rocks from both the Yinshan and Qinling Oldland. However, the elevated concentrations of critical elements ( $\mathrm{Li}, \mathrm{Ga}, \mathrm{Zr}$, and Hf) in the No. 11 coal are primarily inherited from the Yinshan Oldland. The enrichment of the $\mathrm{Se}-\mathrm{Mo}-\mathrm{Cr}-\mathrm{V}-\mathrm{As}-\mathrm{Pb}$ assemblage in No. 11 coal can be ascribed to the influence of both seawater and epigenetic hydrothermal activity.
\end{abstract}

Keywords: superhigh organic sulfur coal; coal geochemistry; critical elements; Late Carboniferous; Sangshuping coal mine

\section{Introduction}

The Weibei Carboniferous-Permian coalfield is a very important coal resource base in Shaanxi, North China [1]. Several researchers have studied the mineralogical and geochemical characteristics of the Weibei coal, and several critical metals, including $\mathrm{Ga}, \mathrm{Li}, \mathrm{Nb}$, and $\mathrm{Zr}$, have been found enriched in the Weibei coalfield, making Weibei coal a potential source for recovery of critical metals. Wang et al. (2011) detected a number of Al hydroxides and oxyhydroxides in the No. 10 coal of the Weibei coalfield and ascribed the enrichment of $\mathrm{Li}-\mathrm{Be}-\mathrm{Ga}-\mathrm{Zr}-\mathrm{Nb}-\mathrm{Mo}-\mathrm{Sn}-\mathrm{W}-\mathrm{U}$ assemblages in Late Carboniferous 
coals to the influence of felsic volcanic debris during the coal formation process [2]. Qin et al. (2019) discussed Ga-Li enrichment in the No.5-2coal from the Dongpo mine, which was attributed to the effect of volcanic ash [3].

Apart from critical elements, the enrichment of potential environmentally significant elements, such as sulfur (especially organic sulfur), As, Se, and $\mathrm{Hg}$ in Weibei coals has also been studied, which is worthy of public attention [4,5]. Luo et al. (2000) found high pyritic and organic sulfur content in No. 5 and No. 11 coal seams, respectively, and investigated the origin of sulfur in different coal seams from the Hancheng mining area [6]. Lu et al. (2003) found that the content of $\mathrm{Hg}$, $\mathrm{Se}, \mathrm{As}, \mathrm{Pb}$, and B is significantly high in Weibei coal [7].

With respect to the high organic sulfur content of No. 11 coal in the Hancheng mining area, it is worth noting that high organic sulfur coals, especially superhigh organic sulfur (SHOS) coals (So, $\mathrm{d}=4-11 \% \mathrm{db}$ ), are not common worldwide, although they have been found in several coal basins in Slovenia [8], Spain [9], Australia [10,11], and China [12-19]. Tang et al. (2015) illustrated that high organic sulfur coal is mainly distributed in Late Permian coals in southern China and in Late Carboniferous coals in northern China [20].A large number of scholars have investigated the characteristics of Late Permian SHOS coals in southern China, e.g., Yishan, Heshan, and Fusui coals from Guangxi [16,18,21-23]; Guiding coals from Guizhou [14]; Chenxi coals from Hunan [24]; Guxu coals from Sichuan [25], and Moxinpo coals from Chongqing [15]. Enrichment of rare metal element assemblages (V-Cr-Se-Mo-Re-U) has been found in these SHOS coals in southern China, which can be predominantly ascribed to hydrothermal activities [14-16,26]. In comparison, characteristics of Late Carboniferous high organic sulfur coals in northern China, for instance, Hedong coals from Shanxi and Sangshuping SHOS coals from the Weibei coalfield, Shaanxi, has been less investigated in the literature $[6,27]$.

To make clean, efficient, and integrated utilization of Weibei coal, it is of great economic and environment significance to investigate the genesis of the high organic sulfur content as well as the enrichment mechanism of critical elements in it. Consequently, the present study focuses on Late Carboniferous SHOS coals of the Sangshuping coal mine from the Weibei coalfield, Shaanxi, and elaborates its geochemical characteristics with special emphasis on the enrichment of potentially hazardous and critical elements in Sangshuping SHOS coals. Subsequently, the possible geneses of elevated critical elements and superhigh organic sulfur content of Sangshuping coals are investigated.

\section{Geological Settings}

The Weibei coalfield lies on the southwestern edge of the North China block at the southeast corner of the Ordos basin and consists of numerous coal beds of the Permo-Carboniferous age [1]. The coalfield is $200 \mathrm{~km}$ long from east to west, $30-55 \mathrm{~km}$ wide from north to south, and has a coal-bearing area of nearly 10,000 $\mathrm{km}^{2}$ that possesses enormous coal resources (up to 83 GT) [28]. The Weibei coalfield is divided into four coal mining districts from east to west (Figure 1), and the studied Sangshuping coal mine area is situated in the Hancheng district [2]. The Late Carboniferous Taiyuan Formation (No.5 to No.11 coal seams) and the Early Permian Shanxi Formation (No. 1 to No.4 coal seams) are the main coal-bearing strata (Figure 2A), which are deposited in a coastal plains and lagoon environment with episodic transgressions and a continental environment, respectively [29]. Note that the No. 5 coal seam is minable throughout the whole coalfield and was formed in a marine-continental transitional environment, while the No. 11 coal seam is only minable in the eastern Hancheng district, viz. the studied area of the present research, and was formed in an occlusive environment with strong seawater influence [30]. 


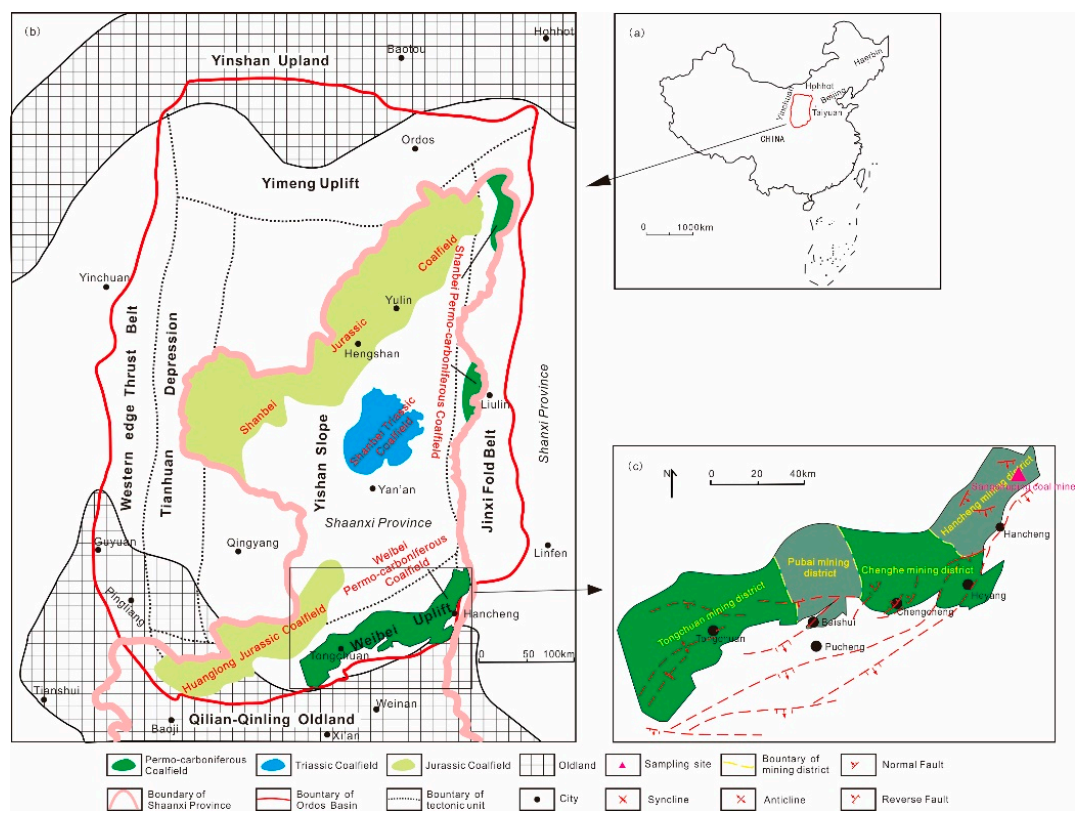

Figure 1. Location of the Sangshuping mine in Hancheng mining district, Weibei coalfield (modified from Li et al., 2020 [31]). (a) Location of the Ordos basin; (b) location of Weibei coalfield in the Ordos basin; (c) sampling sites in the Sangshuping mine, Hancheng mining district of the Weibei coalfield.

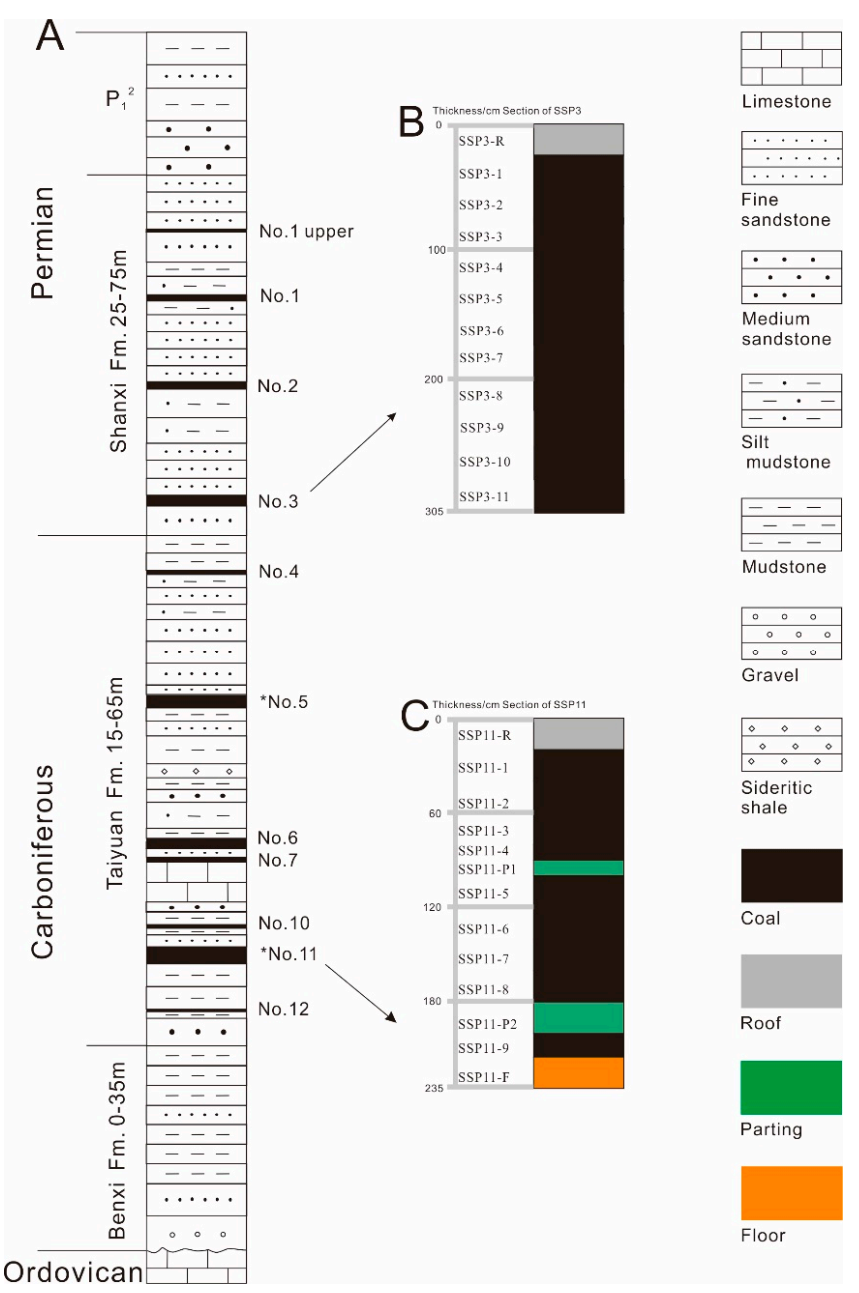

Figure 2. Stratigraphic columns of the Weibei coalfield (A)and sampling distribution in the No. 3 (B) and No. 11 (C) coal seam. 


\section{Sampling and Analytical Methods}

Thirteen bench samples were systematically taken along the underground coal faces of the No. 11 coal seam(the Taiyuan Formation) in the Sangshuping coalmine, Hancheng mining district, following the Chinese Standard Method GB482-2008 [32], including one roof sample (numbered as SSP11-R), one floor sample (SSP11-F), two parting samples(SSP11-P1 and SSP11-P2, respectively), and nine coal bench samples (SSP11-1 to SSP11-9 from top to bottom, Figure 2C). In order to fully elaborate the characteristics and possible genesis of the No. 11 SHOS coals through a comparative study, 12 samples were simultaneously taken from the No.3 coal seam (the Shanxi Formation), including one roof sample (SSP3-R) and 11 coal bench samples (SSP3-1 to SSP3-11 from top to bottom, Figure 2B). The lower portion and floor of the No. 3 coal seam were not accessed for safety reasons. All the samples were crushed and milled to $1 \mathrm{~mm}$ for vitrinite reflectance determination and were continuously milled until they were passed through an 80-mesh sieve and a 200-mesh sieve for proximate analysis and geochemical and mineralogical analyses, respectively.

To determine the moisture content, high-temperature ash (HTA) yield, and volatile matter yield, proximate analysis was performed following the ASTM Standards D3173-11 (2011), D3174-12 (2018), and D3175-18 (2018), respectively [33-35]. The contents of total sulfur and forms of sulfur were analyzed following the ASTM Standards D4239-18a (2018) and D2492-02 (2012), respectively [36,37]. Vitrinite reflectance was measured according to the ASTM Standard D2798-20 (2020) [38].

To identify the mineral phases in the studied bulk coals and noncoal rocks, mineralogical analysis was conducted using powder X-ray diffraction (XRD) with a Bruker D8 A25diffractometer and monochromatic $\mathrm{Cu} K \alpha$ radiation at 2 theta range of $4-60^{\circ}$, step size of $0.19^{\circ}$, and counting time of $0.1 \mathrm{~s} / \mathrm{step}$. An internal reference method was used to semiquantify the mineral contents [39]. The morphology and modes of occurrence of minerals were observed by a field emission scanning electron microscope (FE-SEM) coupled with an energy dispersive X-ray spectrometer (EDX).

Prior to determination of major and trace element concentration, samples were acid-digested according to a two-step digestion method (firstly with $\mathrm{HNO}_{3}$ and secondly with $\mathrm{HF}-\mathrm{HNO}-\mathrm{HClO} 4$ mixture). This was fully described by Querol et al. (1997) and proposed to keep any volatile elements of the bulk samples in solution [40]. Subsequently, the resulting solutions were analyzed by inductively coupled plasma atomic emission spectroscopy (ICP-AES) and inductively coupled plasma mass spectrometry (ICP-MS) for major and trace element concentrations, respectively. Blank samples and South African coal reference material (SARM-19) were analyzed following the same procedure to subtract blanks and check the analytical precision.

\section{Results}

\subsection{Coal Characteristics}

The No. 11 and No. 3 coal were both characterized by low moisture contents (avg. 1.0 and 1.2\%, respectively, air dry basis), low to medium HTA yield (avg. 14.8 and 12.1\%, respectively, dry basis), and low volatile matter yields (avg. 16.3 and 16.2\%, respectively, dry and ash-free basis, Supplementary Table S1). Furthermore, the vitrinite reflectance of No.11 and No.3 coal samples were 1.5 and $1.4 \%$ on average, respectively (Table S1), indicating that both11 and No.3 coal are within the rank of low-volatile bituminous [41]. The relatively higher HTA yields of No. 11 coals (avg. 14.8\% db) than No. 3 coals (avg.12.1\% db) indicate higher terrigenous detrital supply during the formation of No. 11 coal with respect to No. 3 coal.

According to the classification by Chou (2012) [12], the No. 3 coal can be classified as low-sulfur coal $(0.3-0.5 \%$, avg. $0.4 \%$, dry basis), while the No.11 coal belongs to high-sulfur coal (3.7-8.8\%, avg. $5.2 \%$, dry basis).Furthermore, the No. 11 coal was particularly characterized by high organic sulfur content (3.7-5.5\%, avg. $4.4 \%$, dry basis, Table S1), accounting for a dominant proportion of the total sulfur content, belonging to SHOS coal $(4 \% \leq \mathrm{So}, \mathrm{d} \leq 11 \%$ for SHOS coal) [12]. 


\subsection{Coal Geochemistry}

\subsubsection{Major and Trace Element Concentrations}

With respect to the major elements, the No.11 and No. 3 coals were both predominantly composed ofSiO ${ }_{2}$ (avg. 4.6 and 4.3\%, respectively) and $\mathrm{Al}_{2} \mathrm{O}_{3}$ (avg. 3.9 and $4.2 \%$ ) and, to a less extent, $\mathrm{Fe}_{2} \mathrm{O}_{3}$ (avg. 1.4 and $0.4 \%$ ) and $\mathrm{CaO}$ (avg. 1.0 and $1.4 \%$ ), with trace proportions of $\mathrm{K}_{2} \mathrm{O}, \mathrm{Na}_{2} \mathrm{O}$, and $\mathrm{TiO}_{2}$ (Tables S2 and S3). The No. 11 coal had higher $\mathrm{Fe}_{2} \mathrm{O}_{3}$ content than the No. 3 coal, probably due to the higher sulfur and pyrite content in the No. 11 coal (Table S4). In addition, compared to common Chinese coals, the studied coals presented similar or lower contents of major element oxides [42].

In comparison, $\mathrm{SiO}_{2}$ (avg. 24.4\%), $\mathrm{Al}_{2} \mathrm{O}_{3}$ (avg. 19.9\%), and $\mathrm{Fe}_{2} \mathrm{O}_{3}$ (avg. $7.9 \%$ )were the main constituents of the roof/floor/partings of No.11 coal seam. In the roof of No.3 coal, the main components were $\mathrm{SiO}_{2}(40.6 \%)$ and $\mathrm{Al}_{2} \mathrm{O}_{3}(36.2 \%)$, with trace amounts of $\mathrm{Fe}_{2} \mathrm{O}_{3}, \mathrm{CaO}$, and $\mathrm{MgO} . \mathrm{Al}_{2} \mathrm{O}_{3}$ content in the No. 11 and No. 3 coalswere1.4 and 2.5 times higher, respectively, than that of world clays (14.4\%) [43].

Except for $\mathrm{CaO}$, the proportion of the other major element oxides were generally higher in the roofs/floors/partings than in bothNo.11and No.3 coals, which can be attributed to higher mineral content in the roofs/floors/partings than in the coal seams (Table S4) and is indicative of higher detrital input during formation of noncoal rocks. It is worth nothing that the values of $\mathrm{SiO}_{2} / \mathrm{Al}_{2} \mathrm{O}_{3}$ (1.1and 1.0 for No. 11 and No. 3 coals, respectively) were lower than both the average for Chinese coals (1.42) and the theoretical value of kaolinite (1.18), which may be due to extremely low quartz content in the coals (Table S4).

With respect to the trace elements, lithium $(111 \mu \mathrm{g} / \mathrm{g}, \mathrm{CC}=9.3)$ was enriched, and $\mathrm{Ga}(17.5 \mu \mathrm{g} / \mathrm{g}$, $\mathrm{CC}=3.0)$, Se $(3.5 \mu \mathrm{g} / \mathrm{g}, \mathrm{CC}=2.7), \mathrm{Zr}(86.7 \mu \mathrm{g} / \mathrm{g}, \mathrm{CC}=2.7), \mathrm{Mo}(5.1 \mu \mathrm{g} / \mathrm{g}, \mathrm{CC}=2.3), \mathrm{Sn}(2.5 \mu \mathrm{g} / \mathrm{g}$, $\mathrm{CC}=2.3)$, and Hf $(2.6 \mu \mathrm{g} / \mathrm{g}, \mathrm{CC}=2.2)$ were slightly enriched in the No.11 coal (Figure 3A) when compared to the averages for worldwide coals [44]. In comparison, lithium (83.8 $\mu \mathrm{g} / \mathrm{g}, \mathrm{CC}=7.0)$ was also enriched, and $\mathrm{Pb}(\mathrm{CC}=2.7)$ was slightly enriched in the No.3 coal (Figure 3B).

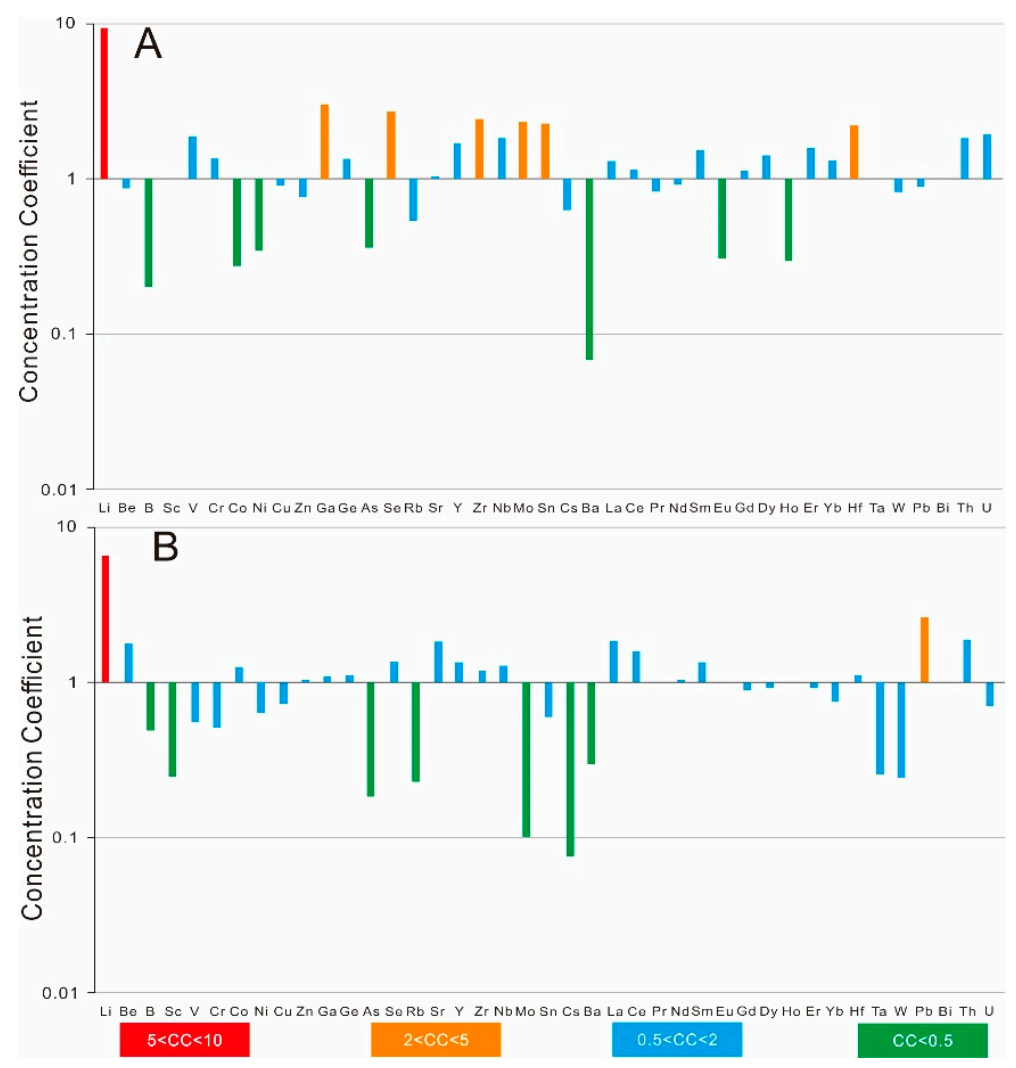

Figure 3. Concentration coefficients (CC) of the trace elements in the No. 11 (A) and No. 3 (B) coals. 
Vertically, these enriched elements presented extraordinarily higher concentrations in the roofs/floors/partings than in the coals of the Sangshuping coal mine (Figures 4 and 5). Based on the vertical variation, there were two enrichment assemblages, viz., $\mathrm{Li}-\mathrm{Ga}-\mathrm{Zr}-\mathrm{Hf}(-\mathrm{Nb}-\mathrm{LREY})$ and $\mathrm{Mo}-\mathrm{Se}-\mathrm{V}-\mathrm{Cr}-\mathrm{As}-\mathrm{Pb}$ assemblage in No. $11 \mathrm{coal}$, which presented similar vertical variation to kaolinite and sulfur, respectively (Figure 4).

Apart from $\mathrm{Li}$, concentrations of most other trace elements were also significantly higher in the roof of No. 3 coal compared to the No. 3coal seam (Figure 5). Vertical variation of $\mathrm{Li}, \mathrm{Ga}, \mathrm{Zr}, \mathrm{Nb}$, and LREY in the No. 3 coal was also similar to that of kaolinite, while elevated $\mathrm{Pb}$ had similar variation to $\mathrm{S}$ and Fe (Figure 5). Note that the high arsenic contents in the roof of the No. 11 coal (CC of 4.9) and the floor of the No. 3 coal (CC of 3.3) may pose a serious threat to the ecosystem, which should arouse attention.

The average concentration of rare earth elements and yttrium (REY) were81 and $93 \mu \mathrm{g} / \mathrm{g}$ in No. 11 and No. 3 coal, respectively, which is higher than the average for world hard coals $(68.6 \mu \mathrm{g} / \mathrm{g})$ [44] but lower than that for common Chinese coals $(136 \mu \mathrm{g} / \mathrm{g})$ [42]. Considering the closer nature of coal to the upper continental crust (UCC), the REY concentrations in the coal were normalized to values for the UCC in the present research $[45,46]$. The UCC-normalized REY enrichment pattern of the No. 11 and No. 3 coals were predominantly the MREY type [47] (Figure 6), while those of the roof/parting/floor of the No. 11 and No. 3 coal seams were characterized by the LREY type (Figure 6). 


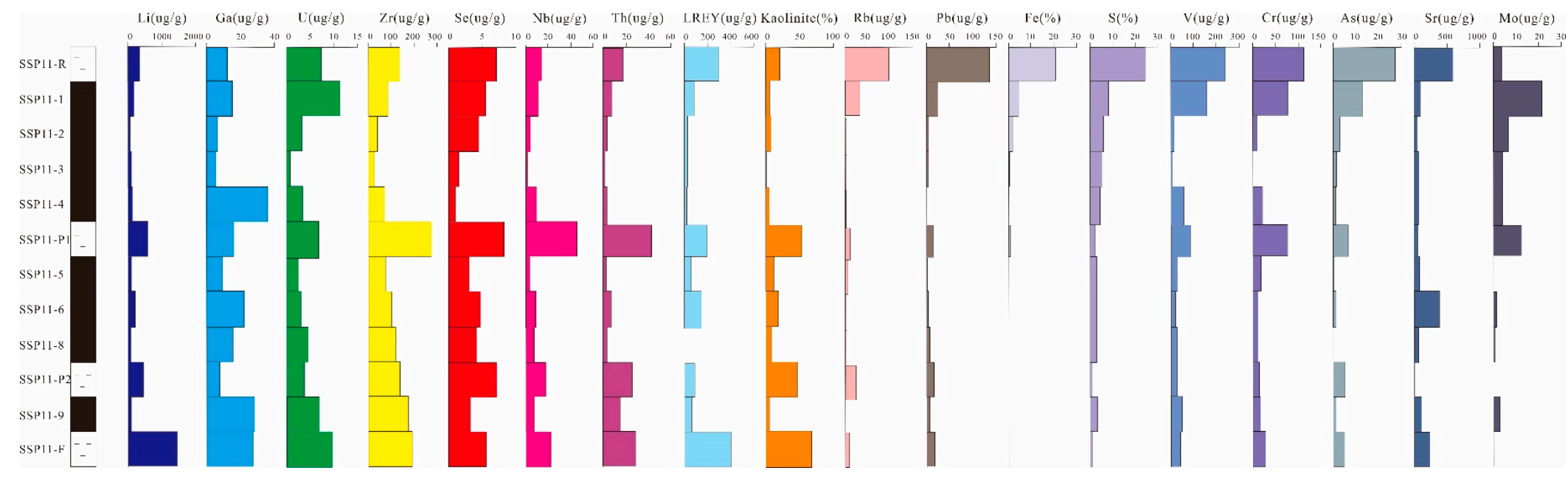

Figure 4. Vertical variation of concentrations of elevated elementsand kaolinite content in the No. 11 coal fromtheSangshuping coal mine.

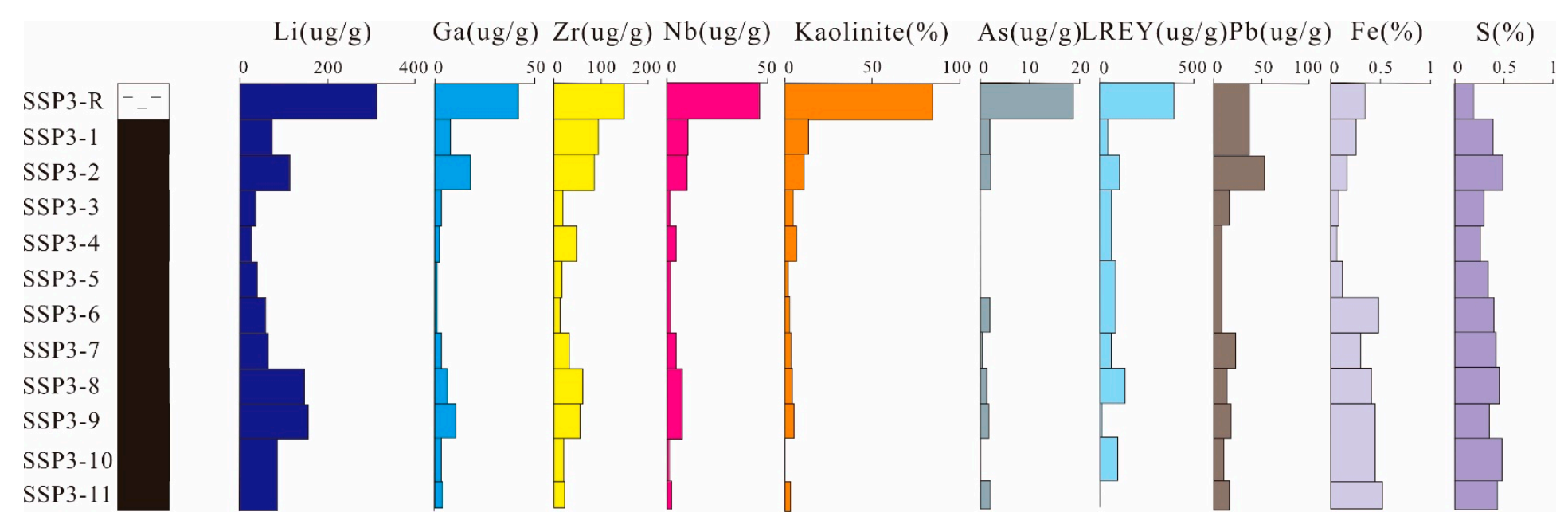

Figure 5. Vertical variation of concentrations of elevated elements and kaolinite content in the No. 3 coal from the Sangshuping coal mine. 


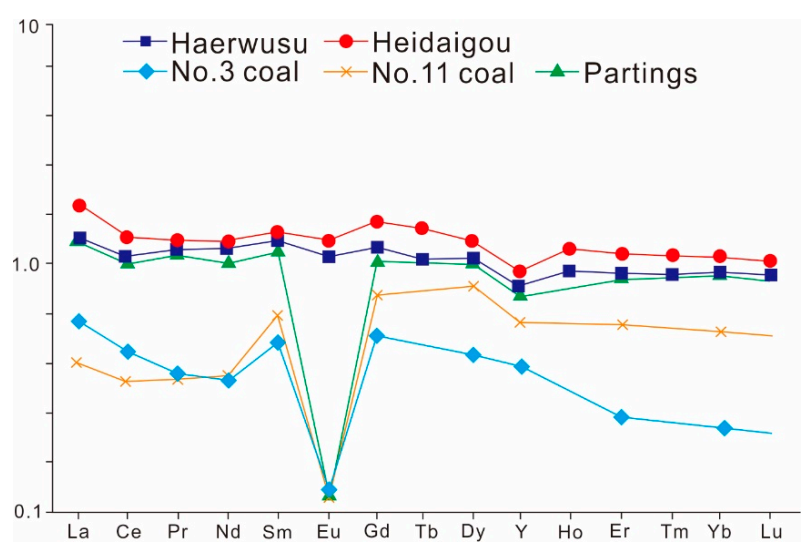

Figure 6. The upper continental crust (UCC)-normalized rare earth elements and yttrium (REY) distribution patterns of the studied samples in comparison to those of Haerwusu [48] and Heidaigou coals [49].

\subsubsection{Modes of Occurrence of Elements}

The following different modes of occurrence of elements in the studied coals were identified based on statistical analysis through Pearson's correlations.

\section{Aluminosilicate Affinities}

As illustrated in Figures 7 and 8, the elevated elements ( $\mathrm{Li}-\mathrm{Ga}-\mathrm{Zr}-\mathrm{Hf}$ assemblage) and several other trace elements, including $\mathrm{Be}, \mathrm{B}, \mathrm{Sc}, \mathrm{Cu}, \mathrm{Nb}, \mathrm{Ta}, \mathrm{W}, \mathrm{Bi}$, Th, and LREY, in the No. 11 coal as well as elevated $\mathrm{Li}$ and $\mathrm{V}, \mathrm{Cr}, \mathrm{As}, \mathrm{Ga}, \mathrm{Zr}, \mathrm{Nb}, \mathrm{Ta}, \mathrm{Hf}, \mathrm{Th}, \mathrm{U}$, and LREY in the No. 3 coal were all highly correlated with HTA yield $(r=0.67-0.94)$ and $\mathrm{Al}_{2} \mathrm{O}_{3}$ content $(r=0.64-0.97)$ on a whole-coal basis, representing dominant aluminosilicate affinities. Furthermore, as aforementioned, the concentrations of these elements showed similar vertical distribution to kaolinite (Figures 4 and 5), indicating their possible occurrence in aluminosilicate minerals in the studied coals.
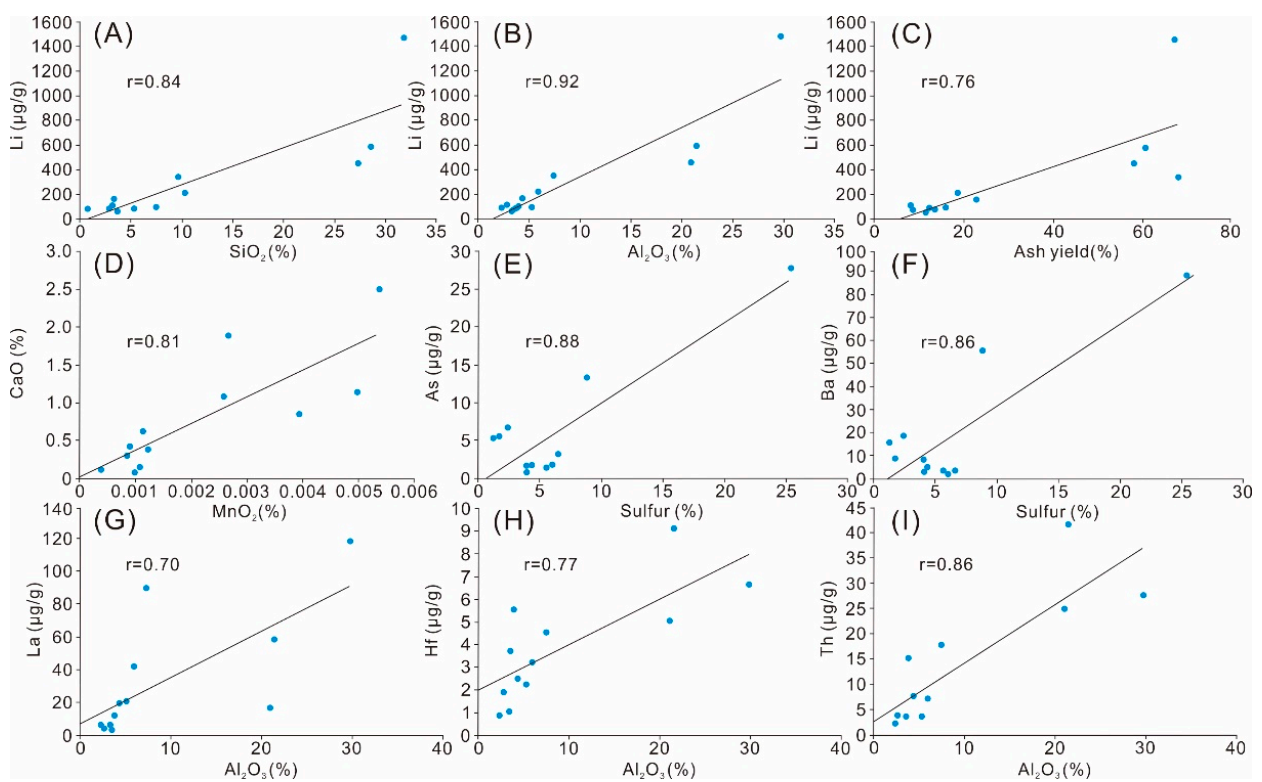

Figure 7. Correlations between selective element concentrations or with high-temperature ash(HTA) yield in the No. 11 coal (on a whole-coal basis). (A-C). Correlations of $\mathrm{Li}$ concentration with $\mathrm{SiO}_{2}$, $\mathrm{Al}_{2} \mathrm{O}_{3}$ content and HTA yield; (D) Correlations between $\mathrm{CaO}$ and $\mathrm{MnO}_{2}$ content; (E-F) Correlations of As and Ba concentration with sulfur content; (G-I) Correlations of La, Hf, and Th concentration with $\mathrm{Al}_{2} \mathrm{O}_{3}$ content. 

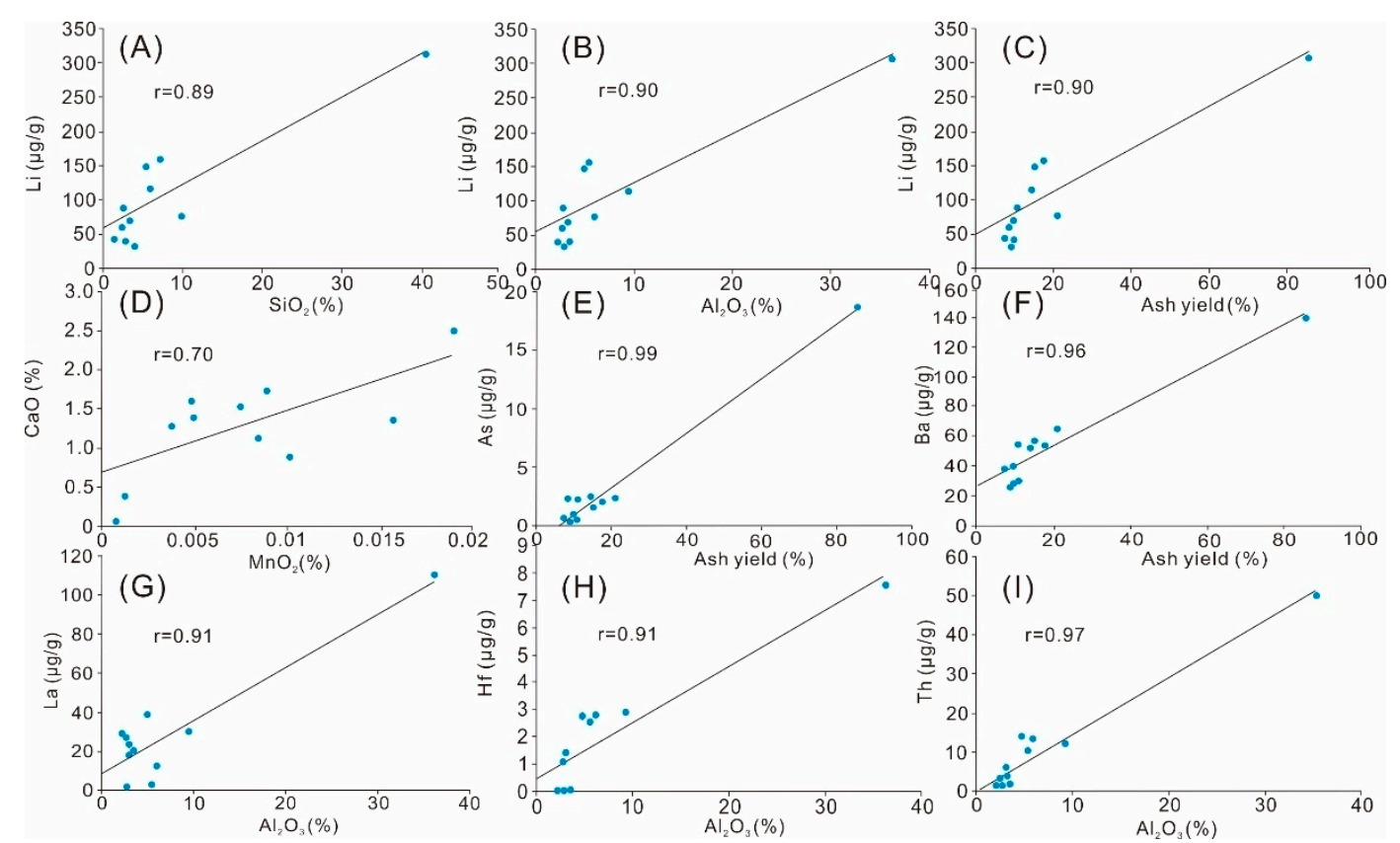

Figure 8. Correlationsbetween selective element concentrations or with HTA yield in the No. 3 coal (on a whole-coal basis). (A-C). Correlations of $\mathrm{Li}$ concentration with $\mathrm{SiO}_{2}, \mathrm{Al}_{2} \mathrm{O}_{3}$ content and HTA yield; (D) Correlations between $\mathrm{CaO}$ and $\mathrm{MnO}_{2}$ content; (E-F) Correlations of As and Ba concentration with HTA yield; (G-I) Correlations of $\mathrm{La}, \mathrm{Hf}$, and Th concentration with $\mathrm{Al}_{2} \mathrm{O}_{3}$ content.

\section{Sulfide Affinities}

Unlike V, Cr, and As in the No. 3 coal, which had an aluminosilicate affinity, elevated V, Cr, and $\mathrm{As}$ as well as $\mathrm{Co}, \mathrm{Rb}, \mathrm{Sr}, \mathrm{Cs}, \mathrm{Ba}, \mathrm{Tl}$, and $\mathrm{Pb}$ in the No. 11 coals were remarkably correlated with total sulfur $(r=0.72-0.92)$, pyritic sulfur $(r=0.76-0.99)$, and iron $(r=0.76-0.98)$ content (Figures 7 and 8 ). Furthermore, each of these elements presented higher correlation coefficients with pyritic sulfur than total sulfur, suggesting that these elements primarily occur with sulfide (e.g., pyrite) in the studied coals.

\section{Carbonate Affinities}

Manganese in the studied coals was obviously correlated with Fe $(r=0.41-0.79)$ and Ca $(r=0.70-0.81)$, indicating a major carbonate affinity (Figures 7 and 8$)$. The carbonate affinity of $\mathrm{Mn}$ is common in coals and has been found in several other coals [50-53].

\section{Discussion}

\subsection{Sediment Provenance}

A number of studies have been conducted to investigate the sediment source for strata of North China block and the Ordos basin [54-57].

The $\mathrm{Al}_{2} \mathrm{O}_{3} / \mathrm{TiO}_{2}$ value, the $\mathrm{Zr} / \mathrm{TiO} 2-\mathrm{Nb} / \mathrm{Y}$ plot, and REY anomalies have been widely applied to reflect the provenance of sedimentary rocks [58], coal deposits $[14,59,60]$, and volcanic ashes in coal-bearing sequence [61-63]. Generally, $\mathrm{Al}_{2} \mathrm{O}_{3} / \mathrm{TiO}_{2}$ ratios of 3-8, 8-21, and 21-70 are indicative of mafic, intermediate, and felsic sediments rocks, respectively [58]. Compared with UCC, europium in coal generally does not present distinct anomalies, and negative Eu anomalies in coals are commonly thought to be derived from detrital supplies of felsic or felsic-intermediate rocks [45].

In the current research, $\mathrm{Al}_{2} \mathrm{O}_{3} / \mathrm{TiO}_{2}$ ratios of the No. 11 and No. 3 coals varied from 10.9 to 44.6 and 15.0 to 83.5, respectively, with an average of 32.3 and 36.0, respectively, and $\mathrm{Al}_{2} \mathrm{O}_{3} / \mathrm{TiO}_{2}$ ratios for 
the roof/floor/partings of the No. 11 and No. 3 coals ranged from 12.5 to 46.1 , respectively, indicating a dominant provenance of intermediate-felsic composition for Sangshuping coals (Figure 9).

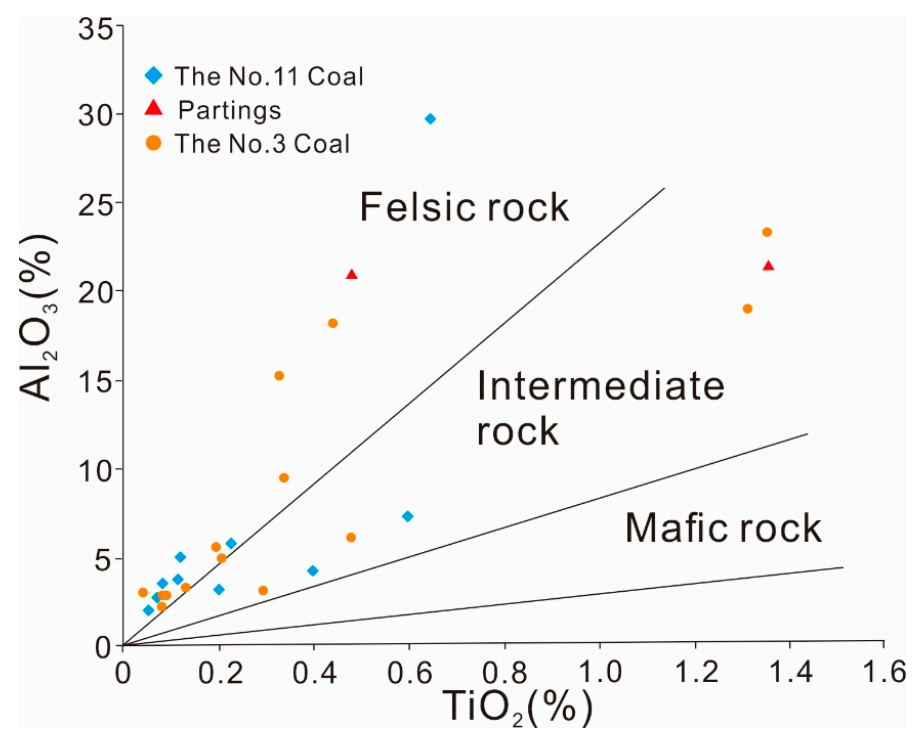

Figure 9. Plots of $\mathrm{Al}_{2} \mathrm{O}_{3}$ versus $\mathrm{TiO}_{2}$ for samples from the No. 11 and No. 3 coal seams, Sangshuping mine, Weibei coalfield.

In the $\mathrm{Zr} / \mathrm{TiO}_{2}-\mathrm{Nb} / \mathrm{Y}$ plot, most of the samples from the two coal seams fell in the fields of trachyandesite, andesite, and rhyodacite/dacite and rhyolite (Figure 10), indicating provenance of felsic-intermediate rocks as well. Furthermore, the No. 11 and No. 3 coals and the noncoal rocks from the Sangshuping coal mine all displayed negative Eu anomalies (Figure 7), which reflects terrigenous supply of felsic or felsic-intermediate composition. This is in accordance with previous research showing that the provenance of the Ordos basin and its surrounding regions all come from the upper crust and are dominated by felsic and intermediate rocks, which consist of ancient metamorphic and sedimentary rocks [56].

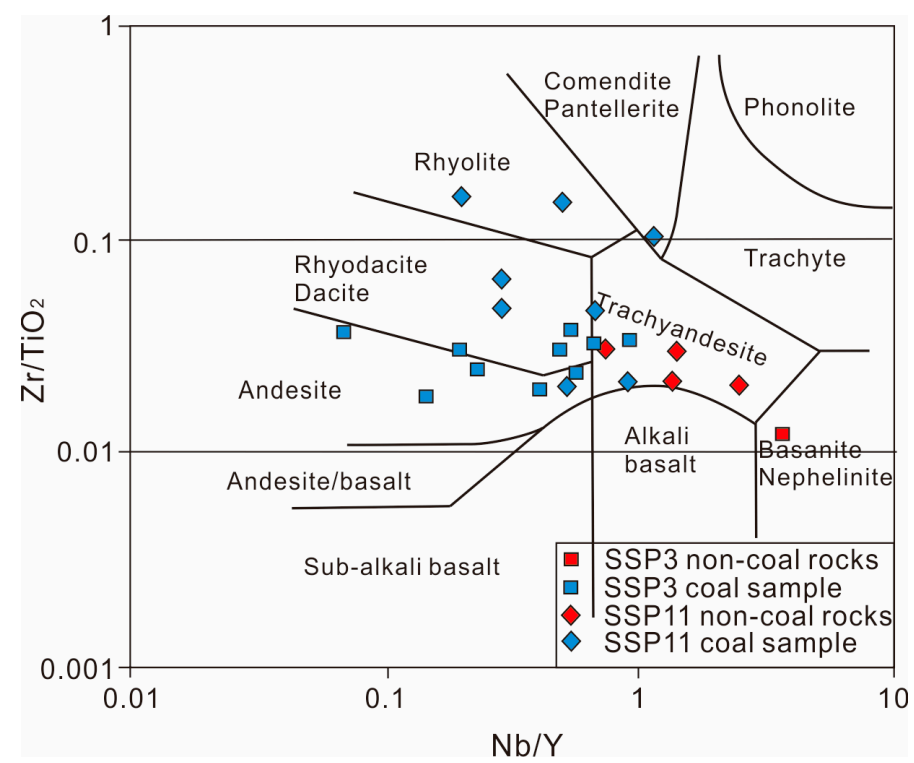

Figure 10. Plots of $\mathrm{Zr} / \mathrm{TiO}_{2}$ vs. $\mathrm{Nb} / \mathrm{Y}$ ratios in samples from the No. 11 and No. 3 coal seams, Sangshuping mine, Weibei coalfield. 
However, compositions of the source and structural setting of provenance in the north and south are different, which is in accordance with the varying trend from oceanic island arc to passive continental margin. The north provenance is mainly derived from plate subduction zones and is related to the tectonic setting of active and passive continental margin until Middle-Late Paleozoic. The source for the northern basin has affinities to Archeozoic and Proterozoic metamorphotic rocks, such as granitic gneiss, diorite gneiss, adamellite, metamorphotic litharenite, and phyllite [56]. According to the China National Administration of Coal Geology (CNACG; 1997), the sediment source for the North China block is mainly from the Yinshan Oldland during the Late Paleozoic (Figure 1) [64]. However, the Weibei coalfieldis situated on the southwestern edge of North China, where the sediment source for the Late Paleozoic strata is controversial. The source for the southern basin has been deeply affected by passive continental margin, and its chemical composition is consistent with those of metamorphic rocks and granites of the Archean-Proterozoic Taihua Group, Qinlin Group, and Kuanping Group, with high $\mathrm{SiO}_{2}$ and $\mathrm{K}_{2} \mathrm{O} / \mathrm{Na}_{2} \mathrm{O}>1$ [56,65]. It is supposed that during the Late Paleozoic, the sediment source for the southcentral part of the North China block and the Ordos basin was controlled by detrital supplies from both the Yinshan tectonic belt to the north and the Central China Orogenic Belt (including Qinling, Dabie, Qilian, and Kunlun Mountain Ranges) to the south [66,67]. Nonetheless, it is still debatable when the provenance in the south started to supply detrital sediments to the Ordos basin. The northern margin where terrigenous input from the southern provenance terminated is also in question $[55,57,68]$.

The provenance from the Yinshan Oldland has the characteristics of abundant feldspar and mica but few quartz contents, which is markedly different from the abundant quartz and lithoclast contents of the Qinling Oldland [65]. With respect to the REY distribution, the sediment source from the North Qinling Orogenic Belt does not present obvious differentiation $[55,69,70]$ or a weak LREY enrichment in the Qilian-Qinling Oldland [65], while that from the Yinshan Oldland is characterized by a distinct light rare earth element (LREE) enrichment [71]. The studied coals did not show distinct REY differentiation with a slight MREY enrichment (Figure 7), indicating that the coals may have been supplied by terrigenous detritus from the Qilian-Qinling Oldland to a certain extent. In comparison, the noncoal samples presented similar REY distribution to the Haerwusu and Heidaigou coals with a slight LREY enrichment and UCC-normalized negative Eu anomaly. In addition, the enrichment of $\mathrm{Li}-\mathrm{Ga}-\mathrm{Zr}-\mathrm{Pb}-\mathrm{Th}$ trace element assemblages in the No. 11 coal also matched with the Haerwusu and Heidaigou coals, which was originally ascribed to the influence of the sediment source from Yinshan Oldland [48]. Furthermore, $\mathrm{K}_{2} \mathrm{O} / \mathrm{Na}_{2} \mathrm{O}$ ratios of the No. 11 coals and most of the No. 3 coals was higher than 1, but the $\mathrm{SiO}_{2}$ and quartz content was not as high as in the Qinling Oldland. Overall, it can be inferred that provenance from both the northern Yinshan Oldland and the southern Qilian-Qinling Oldland of the studied area had a combined influence during the formation process of No. 11 and No. 3 coals in the Sangshuping coal mine.

\subsection{Influence of Seawater}

The No. 11 and No. 3 coal seams in the Sangshuping coal mine was characterized by high and low total sulfur content, respectively, indicating seawater influence during formation of the No. 11 coal seam, which is in accordance with the No. 11 coal formed in coastal plain environment as evidenced by the occurrence of interbedded argillaceous limestones [29]. Apart from sulfur, arsenic concentration was also high in the No. 11 coal, especially in the top of the coal seam, reflecting a strong transgression during the late coalification stage [72].

In addition, the influence of seawater was also reflected by negative Ce anomalies [73], with $\mathrm{CeN} / \mathrm{CeN}^{*}$ values of $<0.5, \sim 0.6-0.9$, and $\sim 0.9-1.0$ indicative of coals formed in oxic, suboxic, and anoxic marine waters, respectively [74]. Apart from SSP11-5 (CeN/CeN* of 0.77) and SSP11-6 (CeN/CeN* of 0.86 ), the $\mathrm{CeN} / \mathrm{CeN}^{*}$ values of most of the No. 11 coal samples were above 0.9 , reflecting a dominant influence of anoxic marine water. By contrast, the average $\mathrm{CeN} / \mathrm{CeN}^{*}$ value in the noncoal 
samples was 0.89 , indicating a relatively oxic environment and more input of terrigenous detritus with respect to the coal formation process.

In addition to different $\mathrm{CeN} / \mathrm{CeN}^{*}$ values, the varying degree of seawater influence and terrigenous material supply during peat accumulation was also evidenced by the various ash yields (Table S1) and $\mathrm{Nb} / \mathrm{Y}$ ratios among coal and noncoal rocks [61]. Compared to the noncoal rocks, coal samples of the No. 11 coal seam presented relatively scattered $\mathrm{Nb} / \mathrm{Y}$ ratios with a wider variation range (Figure 10), which is probably caused by stronger marine influence and less terrigenous input during the coal formation process.

\subsection{Influence of Hydrothermal Solutions}

Previous research has demonstrated that occurrence of cleat- or fracture-infilling minerals in coals is also indicative of hydrothermal activities $[15,22,75,76]$. In the present study, calcite and gypsum were found occurring as fracture fillings, with pyrite or melanterite occasionally infilling the cleats or fractures in the calcite, which suggests an epigenetic origin in their formation (Figure 11a, b). The gypsum cross-cut the fracture-infilling calcite (Figure 11a), indicating that the precipitation of gypsum was later than that of calcite and followed by the crystallization of pyrite due to the influence of hydrothermal fluids penetrating the coal seam. Melanterite also occurred in the form of poreand cleat-infillings in the authigenic kaolinite particles (Figure 11c) and sometimes coexisted with pyrite (Figure 11d), which was crystallized from weathering and oxidation of pyrite in hydrothermal solutions. Furthermore, tobelite was also detected in the Sangshuping coals (Table S4), which is a typical hydrothermal mineral that has been found occurring in several Permo-Carboniferous coals in Chongqing [15], Inner Mongolia [77], and Shanxi [78]. Li et al. (2020) also reported that tobelite occurred in other coal mining districts of the Weibei coalfield [31]. The occurrence of tobelite in coals is attributed to the hydrothermal alteration of existing kaolinite in coals with $\mathrm{NH}_{4}{ }^{+}$from organic matter $[75,79,80]$.

Apart from the mineralogical evidences, influence of hydrothermal activities was also indirectly confirmed by several geochemical evidences. Firstly, although the No. 11 coal was formed in a highly marine-influenced environment, concentration of $\mathrm{SO}_{4}{ }^{2-}$ in paleo-seawater ranged from 5 to $27.6 \mathrm{mmol} / \mathrm{kg}$ in the Phanerozoic [81,82], which was not sufficient enough to generate that high sulfur content $(8.4 \%)$ in coals. Therefore, in addition to the seawater influence, extremely high $\mathrm{S}$ contents in the No. 11 coals were also derived from hydrothermal fluids. Secondly, enrichment of $\mathrm{V}$ and $\mathrm{Cr}$ in coals is generally ascribed to the influence of hydrothermal activities [15]. Concentrations of As, V, Cr, $\mathrm{Mo}$, and $\mathrm{Pb}$ are also high in the top of the No. 11 coal seam, and presents similar vertical distribution with S (Figure 4), which was largely caused by hydrothermal influence. Thirdly, despite of influence of marine depositional environment, high arcenic concentration in coals are also caused by hydrothermal activities [76,83]. Arsenic content is also high in the No. 3 coal formed in a continental environment, probably due to the influence of hydrothermal fluid. Furthermore, the No. 3 and No. 11 coal as well as the non-coal rocks from the Sangshuping mine are characterized by slightly positive Gd anomalies (Figure 7), which most probably caused by activities of hydrothermal fluids $[45,60]$.

Enrichment of a V-Se-Mo-Re-U assemblage in the Late Permian SHOS coals formed in marine carbonate successions in southwestern China was ascribed to input of exfiltrational hydrothermal solutions $[14,16]$. Compared with these Late Permian SHOS coals, even if formed in marine environment and characterized by SHOS content as well, enrichment of a V-Se-Mo-Re-U assemblage was not found; instead, weak enrichment of a Mo-Se- $\mathrm{V}-\mathrm{Cr}-\mathrm{As}-\mathrm{Pb}$ assemblage occurred in Late Carboniferous No. 11 coal of the Sangshuping mine (Figure 4). Uranium was only slightly enriched in the noncoal rocks of the No. 11 coal and coals adjacent to them (Figure 4). Different vertical distributions of $U$ and Mo from V, Cr, and As through the No. 11 coal section indicates that enrichment of these elements can be ascribed to different hydrothermal activities. Although there was no detection of any typical mineral phases related to volcanic ash in the current research, Wang et al. (2009) reported the occurrence of high-temperature quartz and zircon in Weibei coals, which confirmed the influence of felsic volcanic 
debris during the coal formation process [2]. Therefore, a most probable source of the hydrothermal solution can be derived from the volcanic/tectonic activity during accumulation of Late Carboniferous coals in the Weibei coalfield.
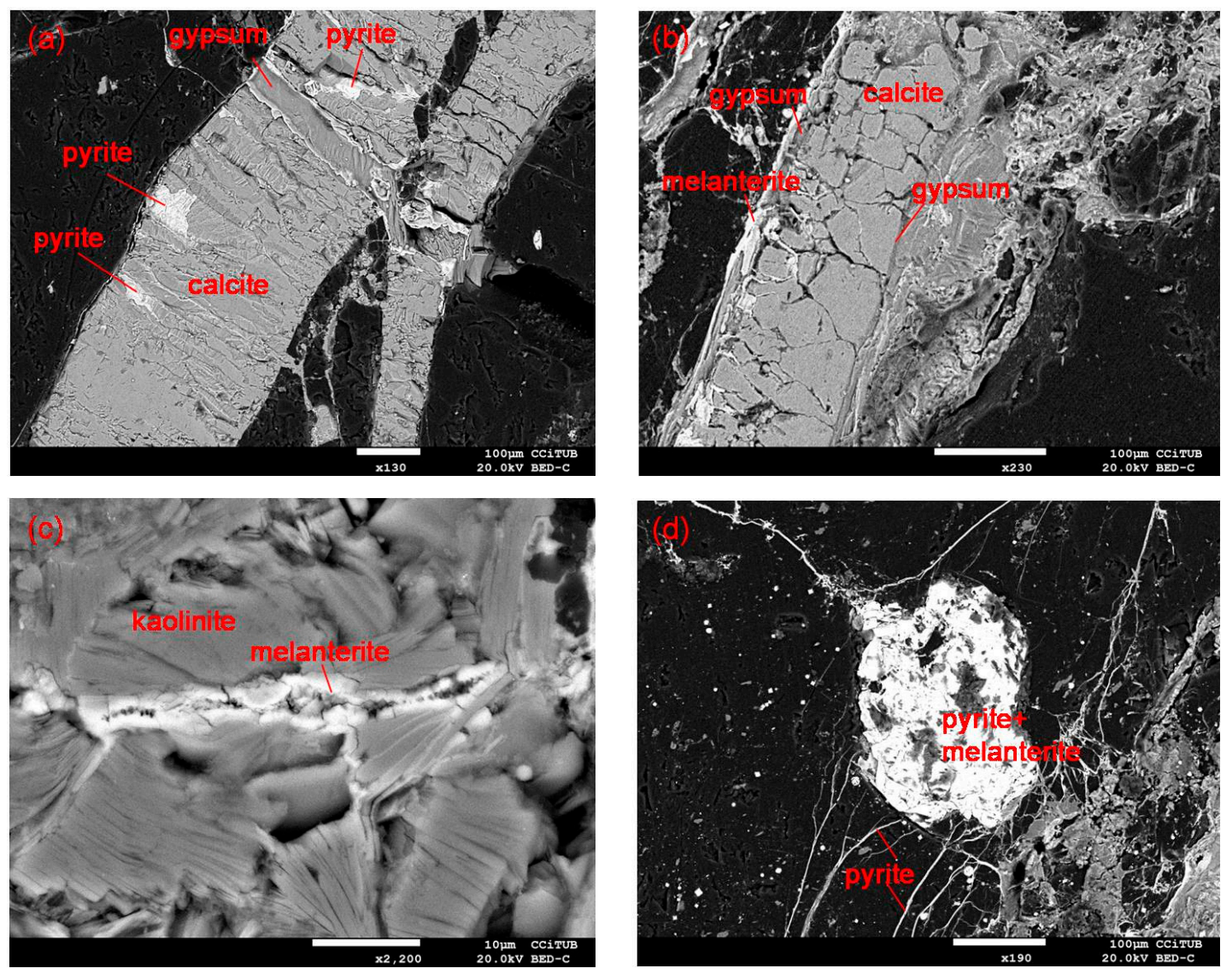

Figure 11. SEM back-scattered images of several cleat-/fracture-infilling minerals in No. 11 coal from the Sangshuping mine. (a) fracture-infilling calcite, gypsum and cleat-infilling pyrite; (b) fracture/cleat-infilling calcite, gypsum and melanterite; (c) authegenic kaolinite and cleat-infilling melanterite (d) fracture/cleat-infilling pyrite and intergrown melanterite.

\subsection{Lithium Enrichment}

As aforementioned, lithium was enriched in both No. $11(C C=9.3)$ and No. $3(C C=7.0)$ coals of the Sangshuping coal mine, Weibei coalfield. Lithium was also found to be enriched in No. 5 coal from Dongpo coal mine [3] and Jinhuashan and Dongdong coal mines in the Weibei coalfield [31]. Furthermore, lithium enrichment has also been found in some coalfields located in the north of the Ordos basin, such as coals from the Antaibo mine in the Ningwu coalfield [84] and from the Guanbanwusu, Heidaigou, Haerwusu, and Tianjiashipan coal mines in the Jungar coalfield $[48,52,85]$.

As stated above, $\mathrm{Li}$ in the Sangshuping coals presented a dominant aluminosilicate affinity, most probably occurring in kaolinite. This is similar to the elevated Li in the Jungar coalfield, which was also found occurring with aluminosilicate minerals, such as kaolinite, chlorite and/or illite, boehmite, and svanbergite in coals [52,86]. It is believed that the YinshanOldland is enriched in Li and the detrital supply from Yinshan Oldland is the primary source for Li enrichment in the Junggar coalfield $[84,85]$. Furthermore, terrigenous materials from the Yinshan Oldland have, to large extent, served as the provenance for No. 11 and No. 3 coal-bearing sequences of the Sangshuping coal mine. Therefore, Li enrichment in the Sangshuping coal mine can probably be attributed to terrigenous sediment source from the Yinshan Oldland. Furthermore, the underlying bauxite of the Benxi formation is considered to be another source of Li due to its high Li content [84], which is raised 
and exposed to the surface during the sedimentation stage [86]. The detrital sediments from the weathered Yinshan Oldland and the exposed bauxite carry high concentration of Li and migrate to the coals by various fluids, e.g., meteoric waters, surface water, and seawater. Thereafter, Li is adsorbed or incorporated by a higher proportion of aluminosilicate minerals (including kaolinite or illite and muscovite) deposited in the coals [87-89].

The average content of $\mathrm{Li}_{2} \mathrm{O}$ in No. 11 and No. 3 coalswere 0.2 and $0.1 \%$, respectively (on an ash basis), which is both below the cutoff grade for $\mathrm{Li}_{2} \mathrm{O}$ in traditional pegmatite-type Li deposits (0.4\%). However, the average $\mathrm{Li}_{2} \mathrm{O}$ content in the coal ash of No. 11coal reached the marginal grade for $\mathrm{Li}_{2} \mathrm{O}$ in $\mathrm{Be}-\mathrm{Li}-\mathrm{Ta}-\mathrm{Nb}$ ore deposits $(0.2 \%)$ [90], indicating that coal ashes of the No. 11 coal are potential source material for Li recovery.

\subsection{Genesis of High Organic Sulfur}

Overall, total sulfur content showed a remarkable increasing trend in the upper section of the No. 11 coal seam and attained the highest value in the roof, such as Fe, V, Cr, and As (Figure 5). This was caused by strong seawater transgression and additional hydrothermal activity during the late coalification stage, which did not pose a remarkable influence on element abundances in the lower section of the coal seam. Furthermore, unlike in the No. 5 medium-high sulfur coal in other coal mines of the Weibei coalfield [2,31], sulfur occurs primarily in organic sulfur form in No. 11 SHOS coal of the Sangshuping mine, with organicsulfur proportion $>90 \%$ in most coal samples and relatively low proportion of pyritic sulfur (Table S1). This is mainly due to the limited Fe supply in the highly occlusive marine environment during the coal formation process; the abundant sulfur reacted with the organic matter in the peat swamp to form organic sulfur compounds [12]. Notably, the coal accumulation broke up due to the continuous strong transgression, and argillaceous limestone was eventually formed at the top of the No. 11 coal with an extremely high content of Fe and total sulfur as well as pyritic sulfur, probably due to sufficient Fe supply from the S-Fe-As-rich hydrothermal solution, which preferentially combined with sulfur to form pyrite.

\section{Conclusions}

The Late Carboniferous No. 11 coal of the Sangshuping mine in Hancheng mining district, Weibei coalfield, is characterized by superhigh organic sulfur content (avg. $4.53 \%$ ), belonging to typical SHOS coal.

The SHOS No. 11 coal is enriched in Li-Ga-Zr-Hf and Mo-Se-V-Cr-As-Pb element assemblages. The former points to a dominant aluminosilicate affinity, and their enhancement can be ascribed to the sediment source region of the Yinshan Oldland, although terrigenous detritus from the Qinling Oldland also serves as the provenance to a certain extent. Due to the highly elevated concentrations of $\mathrm{Li}_{2} \mathrm{O}$, coal ash of the No. 11 coal may be considered as a promising source for Li recovery. In contrast, the latter presents a high sulfide affinity. Similar to the high $S$ content in coal, their enrichment can be ascribed to the influence of both seawater and epigenetic hydrothermal activity.

High sulfur content occurs primarily in the form of organic sulfur in the No. 11 coal but in a dominant pyritic form in the roof. This is ascribed to sulfur reacting with organic matter in the peat swamp to form organic sulfur because of the insufficient supply of Fe available in seawater during the coal formation process. However, due to a strong seawater transgression and hydrothermal activity during the late coalification stage, sufficient supply of Fe was available from the S-Fe-As-rich hydrothermal solution and preferentially reacted with sulfur to form pyritic sulfur.

Supplementary Materials: The following are available online at http://www.mdpi.com/1996-1073/13/24/6660/s1, Table S1: Proximate analyses (\%), forms of sulfur (\%), and vitrinite random reflectance (\%) of No.11 and No.3 coals from the Sangshuping Coal Mine, Weibei Coalfield, Table S2: Percentages of major-element oxides (\%) and concentrations of trace elements $(\mu \mathrm{g} / \mathrm{g})$ of the No.11 coal from the Sangshuping coal mine, Weibei Coalfield (on whole coal basis), Table S3: Percentages of major-element oxides (\%) and concentrations of trace elements ( $\mu \mathrm{g} / \mathrm{g})$ of the No.3 coal from the Sangshuping coal mine, Weibei Coalfield (on whole coal basis), Table S4: Semi-quantitative compositions of mineralogical phases in the studied samples determined by XRD (\%, on whole-coal basis). 
Author Contributions: Conceptualization, J.L. and X.Z.; methodology, J.L. and N.M.; investigation, J.L., P.W., G.Y., L.P., B.L., and Y.S.; writing-original draft preparation, J.L. and P.W.; writing-review and editing, J.L. and X.Q.; supervision, X.Z. and X.Q.; project administration, J.L. All authors have read and agreed to the published version of the manuscript.

Funding: This research was funded by the National Key R\&D Program of China (No. 2018YFF0215400), the National Science Foundation of China (Nos. 41972179, 41972180), and the Fundamental Research Funds for the Central Universities (No. CUGCJ1819).

Acknowledgments: The authors appreciate the reviewers for their useful comments and suggestions to improve the quality of the manuscript.

Conflicts of Interest: There is no conflict of interest.

\section{References}

1. Wang, S.; Wang, X. Potentially useful elements (Al, Fe, Ga, Ge, U) in coal gangue: A case study in Weibei coal mining area, Shaanxi Province, northwestern China. Environ. Sci. Pollut. Res. 2018, 25, 11893-11904. [CrossRef]

2. Wang, X.; Dai, S.; Ren, D.; Yang, J. Mineralogy and geochemistry of Al-hydroxide/oxyhydroxide mineral-bearing coals of Late Paleozoic age from the Weibei coalfield, southeastern Ordos Basin, North China. Appl. Geochem. 2011, 26, 1086-1096. [CrossRef]

3. Qin, G.; Cao, D.; Wei, Y.; Wang, A.; Liu, J. Mineralogy and Geochemistry of the No. 5-2 High-Sulfur Coal from the Dongpo Mine, Weibei Coalfield, Shaanxi, North China, with Emphasis on Anomalies of Gallium and Lithium. Minerals 2019, 9, 402. [CrossRef]

4. Mi, J.; Ren, J.; Wang, J.C.; Bao, W.R.; Xie, K.C. Ultrasonic and Microwave Desulfurization of Coal in Tetrachloroethylene. Energy Sources Part A Recovery Util. Environ. Eff. 2007, 29, 1261-1268. [CrossRef]

5. Yang, Z.Y.; Wang, S.T.; Tan, C.; Li, Y.H. Desulfurization Effect of High-Sulfur Weibei Coal of Assisted by Microwave Irradiation and Ultrasonic Wave. Adv. Mater. Res. 2014, 1070, 501-504. [CrossRef]

6. Luo, K.; Wang, W.; Yao, G.; Duanmu, H.; Mi, J.; Zhang, H. Sulfur content of permo-carboniferous coal and its geneses in Hancheng mine. J. Xi'an Univ. Sci. Technol. 2000, 20, 289-292, 298, (In Chinese with English Abstract).

7. Lu, X. Characteristics of environmental geochemistry of Se in Coals of Shaanxi province. J. Shaanxi Norm. Univ. (Natl. Sci. Ed.) 2003, 31, 107-112, (In Chinese with English Abstract).

8. Damste, J.A.S.; White, C.M.; Green, J.B.; de Leeuw, J.W. Organosulfur compounds in sulfur-rich Raša coal. Energy Fuels 1999, 13, 728-738. [CrossRef]

9. Querol, X.; Cabrera, L.; Pickel, W.; López-Soler, A.; Hagemann, H.W.; Fernández-Turiel, J.L. Geological controls on the coal quality of the Mequinenza subbituminous coal deposit, northeast Spain. Int. J. Coal Geol. 1996, 29, 67-91. [CrossRef]

10. Smith, J.W.; Batts, B.D. The distribution and isotopic composition of sulfur in coal. Geochim. Cosmochim. Acta 1974, 38, 121-133. [CrossRef]

11. Ward, C.R.; Li, Z;; Gurba, L.W. Variations in elemental composition of macerals with vitrinite reflectance and organic sulphur in the Greta Coal Measures, New South Wales, Australia. Int. J. Coal Geol. 2007, 69, 205-219. [CrossRef]

12. Chou, C.-L. Sulfur in coals: A review of geochemistry and origins. Int. J. Coal. Geol. 2012, 100, 1-13. [CrossRef]

13. Dai, S.; Ren, D.; Zhou, Y.; Chou, C.-L.; Wang, X.; Zhao, L.; Zhu, X. Mineralogy and geochemistry of a superhigh-organic-sulfur coal, Yanshan Coalfield, Yunnan, China: Evidence for a volcanic ash component and influence by submarine exhalation. Chem. Geol. 2008, 255, 182-194. [CrossRef]

14. Dai, S.; Seredin, V.V.; Ward, C.R.; Hower, J.C.; Xing, Y.; Zhang, W.; Song, W.; Wang, P. Enrichment of U-Se-Mo-Re-V in coals preserved within marinecarbonate successions: Geochemical and mineralogical datafrom the Late Permian Guiding Coalfield, Guizhou, China. Miner. Deposita 2015, 50, 159-186. [CrossRef]

15. Dai, S.; Xie, P.; Jia, S.; Ward, C.R.; Hower, J.C.; Yan, X.; French, D. Enrichment of U-Re-V-Cr-Se and rare earth elements in the Late Permian coals of the Moxinpo Coalfield, Chongqing, China: Genetic implications from geochemical and mineralogical data. Ore Geol. Rev. 2017, 80, 1-17. [CrossRef]

16. Dai, S.; Xie, P.; Ward, C.R.; Yan, X.; Guo, W.; French, D.; Graham, I.T. Anomalies of rare metals in Lopingian super-high-organic-sulfur coals from the Yishan Coalfield, Guangxi, China. Ore Geol. Rev. 2017, 88, 235-250. [CrossRef]

17. Lei, J.; Ren, D.; Tang, Y.; Chu, X.; Zhao, R. Sulfur-accumulating model of superhigh organosulfur coal from Guiding, China. Chin. Sci. Bull. 1994, 39, 1817-1821. 
18. Shao, L.; Jones, T.; Gayer, R.; Dai, S.; Li, S.; Jiang, Y.; Zhang, P. Petrology and geochemistry of the high-sulphur coals from the Upper Permian carbonate coal measures in the Heshan coalfield, southern China. Int. J. Coal Geol. 2003, 55, 1-26. [CrossRef]

19. Zeng, R.; Zhuang, X.; Koukouzas, N.; Xu, W. Characterization of trace elements in sulphur-rich Late Permian coals in the Heshan coal field, Guangxi, South China. Int. J. Coal Geol. 2005, 61, 87-95. [CrossRef]

20. Tang, Y.; He, X.; Cheng, A.; Li, W.; Deng, X.; Wei, Q.; Li, L. Occurrence and sedimentary control of sulfur in coals of China. J. China Coal Soc. 2015, 40, 1977-1988.

21. Dai, S.; Zhang, W.; Seredin, V.V.; Ward, C.R.; Hower, J.C.; Song, W.; Wang, X.; Li, X.; Zhao, L.; Kang, H.; et al. Factors controlling geochemical and mineralogical compositions of coals preserved within marine carbonate successions: A case study from the Heshan Coalfield, southern China. Int. J. Coal Geol. 2013, 109-110, 77-100. [CrossRef]

22. Dai, S.; Zhang, W.; Ward, C.R.; Seredin, V.V.; Hower, J.C.; Li, X.; Song, W.; Wang, X.; Kang, H.; Zheng, L.; et al. Mineralogical and geochemical anomalies of late Permian coals from the Fusui Coalfield, Guangxi Province, Southern China: Influences of terrigenous materials and hydrothermal fluids. Int. J. Coal Geol. 2013, 105, 60-84. [CrossRef]

23. Dai, S.; Xie, P.; French, D.; Ward, C.R.; Graham, I.T.; Yan, X.; Guo, W. The occurrence of buddingtonite in super-high-organic-sulphur coals from the Yishan Coalfield, Guangxi, southern China. Int. J. Coal Geol. 2018, 195, 347-361. [CrossRef]

24. Li, W.; Tang, Y. Characteristics of the rare earth elements in a high organic sulfur coal from Chenxi, Hunan province. J. Fuel Chem. Technol. 2013, 41, 540-549.

25. Dai, S.; Liu, J.; Ward, C.R.; Hower, J.C.; French, D.; Jia, S.; Hood, M.M.; Garrison, T.M. Mineralogical and geochemical compositions of Late Permian coals and host rocks from the Guxu Coalfield, Sichuan Province, China, with emphasis on enrichment of rare metals. Int. J. Coal Geol. 2016, 166, 71-95. [CrossRef]

26. Liu, J.; Yang, Z.; Yan, X.; Ji, D.; Yang, Y.; Hu, L. Modes of occurrence of highly-elevated trace elements in superhigh-organic-sulfur coals. Fuel 2015, 156, 190-197. [CrossRef]

27. Zhao, Q.; Tang, Y.; Li, W.; Wang, S.; Deng, X.; Yu, X. Compositional characteristics of sulfur-containing compounds in high sulfur coals. Energy Explor. Explor. 2014, 32, 301-316. [CrossRef]

28. Zhang, X.; Wu, H.; Li, W. Analysis of coal reserves in Shaanxi Province. Inn. Mong. Coal Econ. 2015, 6, 200, 210. (In Chinese)

29. Yao, Y.; Liu, D.; Tang, D.; Tang, S.; Che, Y.; Huang, W. Preliminary evaluation of the coalbed methane production potential and its geological controls in the Weibei Coalfield, Southeastern Ordos Basin, China. Int. J. Coal Geol. 2009, 78, 1-15. [CrossRef]

30. Lai, A. Sedimentary Characteristics and Accumulation of Coal Measure in Weibei Mining Area. Master's Thesis, Xi'an University of Science and Technology, Xi'an, China, 2014.

31. Li, J.; Zhuang, X.; Querol, X.; Moreno, N.; Yang, G.; Pan, L.; Li, B.; Shangguan, Y.; Pan, Z.; Liu, B. Enrichment of $\mathrm{Nb}-\mathrm{Ta}-\mathrm{Zr}-\mathrm{W}-\mathrm{Li}$ in the Late Carboniferous Coals from the Weibei Coalfield, Shaanxi, North China. Energies 2020, 13, 4818. [CrossRef]

32. GB/T 482-2008 (National Standard of China). Sampling of Coal in Seam; China National Coal Association: Beijing, China, 2008. (In Chinese)

33. ASTM Standard D3173-11. Standard Test Method for Moisture in the Analysis Sample of Coal and Coke; ASTM International: West Conshohocken, PA, USA, 2011.

34. ASTM Standard D3174-12. Standard Test Method for Ash in the Analysis Sample of Coal and Coke from Coal; ASTM International: West Conshohocken, PA, USA, 2018.

35. ASTM Standard D3175-18. Standard Test Method for Volatile Matter in the Analysis Sample of Coal and Coke; ASTM International: West Conshohocken, PA, USA, 2018.

36. ASTM Standard D4239-18a. Standard Test Method for Sulfur in the Analysis Sample of Coal and Coke Using High-Temperature Tube Furnace Combustion; ASTM International: West Conshohocken, PA, USA, 2018.

37. ASTM Standard D2492-02. Standard Test Method for Forms of Sulfur in Coal; ASTM International: West Conshohocken, PA, USA, 2012.

38. ASTM D2798-20. Standard Test Method for Microscopical Determination of the Vitrinite Reflectance of Coal; ASTM International: West Conshohocken, PA, USA, 2020.

39. Chung, F.H. Quantitative interpretation of X-ray diffraction patterns of mixtures: I. Matrix flushing method for quantitative multicomponent analysis. J. Appl. Crystalogr. 1974, 7, 519-525. [CrossRef] 
40. Querol, X.; Whateley, M.K.G.; Fernandez Turiel, J.L.; Tuncali, E. Geological controls on the mineralogy and geochemistry of the Beypazari lignite, central Anatolia, Turkey. Int. J. Coal Geol. 1997, 33, 255-271. [CrossRef]

41. ASTM Standard D388-12. Standard Classification of Coals by Rank; ASTM International: West Conshohocken, PA, USA, 2012.

42. Dai, S.; Ren, D.; Chou, C.-L.; Finkelman, R.B.; Seredin, V.V.; Zhou, Y. Geochemistry of trace elements in Chinese coals: A review of abundances, genetic types, impacts on human health, and industrial utilization. Int. J. Coal Geol. 2012, 94, 3-21. [CrossRef]

43. Grigoriev, N.A. Chemical Element Distribution in the Upper Continental Crust; UBRAS: Ekaterinburg, Russia, 2009; p. 382. (In Russian)

44. Ketris, M.P.; Yudovich, Y.E. Estimations of Clarkes for Carbonaceous biolithes: World averages for trace element contents in black shales and coals. Int. J. Coal Geol. 2009, 78, 135-148. [CrossRef]

45. Dai, S.; Graham, I.T.; Ward, C.R. A review of anomalous rare earth elements and yttrium in coal. Int. J. Coal Geol. 2016, 159, 82-95. [CrossRef]

46. Taylor, S.R.; McLennan, S.M. The Continental Crust: Its Composition and Evolution; Blackwell: Oxford, UK, $1985 ;$ p. 312.

47. Seredin, V.V.; Dai, S. Coal deposits as potential alternative sources for lanthanides and yttrium. Int. J. Coal Geol. 2012, 94, 67-93. [CrossRef]

48. Dai, S.; Li, D.; Chou, C.-L.; Zhao, L.; Zhang, Y.; Ren, D.; Ma, Y.; Sun, Y. Mineralogy and geochemistry of boehmite-rich coals: New insights from the Haerwusu Surface Mine, Jungar Coalfield, Inner Mongolia, China. Int. J. Coal Geol. 2008, 74, 185-202. [CrossRef]

49. Dai, S.; Ren, D.; Chou, C.-L.; Li, S.; Jiang, Y. Mineralogy and geochemistry of the No.6 coal (Pennsylvanian) in the Junger Coalfield, Ordos Basin, China. Int. J. Coal Geol. 2006, 66, 253-270. [CrossRef]

50. Finkelman, R.B. Modes of occurrence of potentially hazardous elements in coal: Levels of confidence. Fuel Process. Technol. 1994, 39, 21-34. [CrossRef]

51. Finkelman, R.B.; Palmer, C.A.; Wang, P. Quantification of the modes of occurrence of 42 elements in coal. Int. J. Coal Geol. 2018, 185, 138-160. [CrossRef]

52. Li, J.; Zhuang, X.; Yuan, W.; Liu, B.; Querol, X.; Font, O.; Moreno, N.; Li, J.; Gang, T.; Liang, G. Mineral composition and geochemical characteristics of the Li-Ga-rich coals in the Buertaohai-Tianjiashipan mining district, Jungar Coalfield, Inner Mongolia. Int. J. Coal Geol. 2016, 167, 157-175. [CrossRef]

53. Swaine, D.J. Trace Elements in Coal; Butterworth and Co. Ltd: London, UK, 1990; 278p.

54. Wang, Z.; Zhang, J.; Chen, H. Study of the dispositional provenance of the terrigenous detritus in Ordos Basin in Late Paleozoic Era. J. Chengdu Univ. Technol. 2001, 28, 7-12, (In Chinese with English Abstract).

55. Chen, Q.; Li, W.; Wang, Y.; Jin, S.; Gao, Y. The analysis of sediment provenance in Early-Middle period of Late Paleozoic in the Southwest of Ordos Basin. Geoscince 2006, 20, 628-634, (In Chinese with English Abstract).

56. Chen, Q.; Li, W.; Hu, X.; Li, K.; Pang, J.; Guo, Y. Tectonic setting and provenance analysis of late Paleozoic sedimentary rocks in the Ordos Basin. Acta Geol. Sin. 2012, 86, 1150-1162, (In Chinese with English Abstract).

57. Qu, H.; Ma, Q.; Gao, S.; Mei, Z.; Miao, J. Analyses on provenance of the Permian in the southeastern Ordos Basin. Acta Geol. Sin. 2011, 85, 979-986, (In Chinese with English Abstract).

58. Hayashi, K.-I.; Fujisawa, H.; Holland, H.D.; Ohmoto, H. Geochemistry of $\sim 1.9$ Ga sedimentary rocks from northeastern Labrador, Canada. Geochim. Cosmochim. Acta 1997, 61, 4115-4137. [CrossRef]

59. Dai, S.; Li, T.; Jiang, Y.; Ward, C.R.; Hower, J.C.; Sun, J.; Liu, J.; Song, H.; Wei, J.; Li, Q.; et al. Mineralogical and geochemical compositions of the Pennsylvanian coal in the Hailiushu Mine, Daqingshan Coalfield, Inner Mongolia, China: Implications of sediment-source region and acid hydrothermal solutions. Int. J. Coal Geol. 2015, 137, 92-110. [CrossRef]

60. Hower, C.J.; Eble, F.C.; Keefe, M.K.J.; Dai, S.; Wang, P.; Xie, P.; Liu, J.; Ward, R.C.; French, D. Petrology, Palynology, and Geochemistry of Gray Hawk Coal (Early Pennsylvanian, Langsettian) in Eastern Kentucky, USA. Minerals 2015, 5, 592-622. [CrossRef]

61. Zhao, L.; Dai, S.; Nechaev, V.P.; Nechaeva, E.V.; Grahame, I.T.; French, D. Enrichment origin of critical elements ( $\mathrm{Li}$ and rare earth elements) and a Mo-U-Se-Re assemblage in Pennsylvanian anthracite from the Jincheng Coalfield, southeastern Qinshui Basin, northern China. Ore Geol. Rev. 2019, 115, 103184. [CrossRef]

62. Zhou, Y.; Ren, Y.; Tang, D.; Bohor, B. Characteristics of zircons from volcanic ash-derived tonsteins in Late Permian coal fields of eastern Yunnan, China. Int. J. Coal Geol. 1994, 25, 243-264. [CrossRef] 
63. Zhou, Y.; Bohor, B.F.; Ren, Y. Trace element geochemistry of altered volcanic ash layers (tonsteins) in Late Permian coal-bearing formations of eastern Yunnan and western Guizhou Provinces, China. Int. J. Coal Geol. 2000, 44, 305-324. [CrossRef]

64. CNACG, (China National Administration of Coal Geology). Late Paleozoic Coal Geology of North China Platform; Shanxi Science and Technology Press: Taiyuan, Shanxi, China, 1997; (In Chinese with English Abstract).

65. Wan, Y. Study on the Spatial Coupling Relation of between the Sediment Source and Diagenesis of Yanchang Formation in southern Ordos Basin. Master's Thesis, Chengdu University of Technology, Chengdu, China, 2011. (In Chinese with English Abstract).

66. Zhu, X.-Q.; Zhu, W.-B.; Ge, R.-F.; Wang, X. Late paleozoic provenance shift in the south-central North China Craton: Implications for tectonic evolution and crustal growth. Gondwana Res. 2014, 25, 383-400. [CrossRef]

67. Zhu, H.; Zhang, W.; Ning, S.; Han, L.; Deng, X. Aluminum Distribution in North China Permo-Carboniferous Coal and Its Resource Prospect. Coal Geol. China 2018, 30, 21-25+29, (In Chinese with English Abstract).

68. Li, Y. Research of Lithofacies and Paleogeography of the Late Paleozoic Era in Southern Ordos Basin. Master's Dissertation, Northwest University, Xi'an, Shaanxi, China, 2013. (In Chinese with English Abstract).

69. Wang, T.; Wang, X.; Tian, W.; Zhang, C.; Li, W.; Li, S. North Qinling Paleozoicgranite associations and their variation in space and time: Implications for orogenic processes in the orogens of central China. Sci. China Ser. D Earth Sci. 2009, 52, 1359-1384. [CrossRef]

70. Qin, Z.; Wu, Y.; Siebel, W.; Gao, S.; Wang, H.; Abdallsamed, M.I.M.; Zhang, W.; Yang, S. Genesis of adakitic granitoids by partial melting of thickened lower crust and its implications for early crustal growth: A case study from the Huichizi pluton, Qinling orogen, central China. Lithos 2015, 238, 1-12. [CrossRef]

71. Jian, P.; Kröner, A.; Windley, B.F.; Zhang, Q.; Zhang, W.; Zhang, L. Episodic mantl melting-crustal reworking in the late Neoarchean of the northwestern North China Craton: Zircon ages of magmatic and metamorphic rocks from the Yinshan Block. Precambr. Res. 2012, 222-223, 230-254. [CrossRef]

72. Liu, G.; Yang, P.; Peng, Z.; Chou, C. Petrographic and geochemical contrasts and environmentally significant trace elements in marine-influenced coal seams, Yanzhoumining area, China. J. Asian Earth Sci. 2004, 23, 491-506. [CrossRef]

73. Murray, R.W.; Buchholtz, T.; Brink, M.R.; Jones, D.L.; Gerlach, D.C.; Russ, G.P. Rare earth elements as indicators of different marine depositional environments in chert and shale. Geology 1990, 18, 268-272. [CrossRef]

74. Chen, J.; Algeo, T.J.; Zhao, L.; Chen, Z.-Q.; Cao, L.; Zhang, L.; Li, Y. Diagenetic uptake of rare earth elements by bioapatite, with an example from Lower Triassic conodonts of South China. Earth-Sci. Rev. 2015, 149, 181-202. [CrossRef]

75. Permana, A.K.; Ward, C.R.; Li, Z.; Gurba, L.W. Distribution and origin of minerals in high-rank coals of the South Walker Creek area, Bowen Basin, Australia. Int. J. Coal Geol. 2013, 116-117, 185-207. [CrossRef]

76. Li, J.; Zhuang, X.; Querol, X.; Font, O.; Izquierdo, M.; Wang, Z. New data on mineralogy and geochemistry of high-Ge coals in the Yimin coalfield, Inner Mongolia, China. Int. J. Coal Geol. 2014, 125, 10-21. [CrossRef]

77. Dai, S.; Zou, J.; Jiang, Y.; Ward, C.R.; Wang, X.; Li, T.; Xue, W.; Liu, S.; Tian, H.; Sun, X.; et al. Mineralogical and geochemical compositions of the Pennsylvanian coal in the Adaohai Mine, Daqingshan Coalfield, Inner Mongolia, China: Modes of occurrence and origin of diaspore, gorceixite, and ammonianillite. Int. J. Coal Geol. 2012, 94, 250-270. [CrossRef]

78. Zheng, Q.; Liu, Q.; Shi, S. Mineralogy and geochemistry of ammonian illite in intraseam partings in Permo-Carboniferous coal of the Qinshui coalfield, North China. Int. J. Coal Geol. 2016, 153, 1-11. [CrossRef]

79. Boudou, J.P.; Schimmelmann, A.; Ader, M.; Mastalerz, M.; Sebilo, M.; Gengembre, L. Organic nitrogen chemistry during low-grade metamorphism. Geochim. Cosmochim. Acta 2008, 72, 1199-1221. [CrossRef]

80. Nieto, F. Characterization of coexisting NH4- and K-micas in very low-grade metapelites. Am. Mineral. 2002, 87, 205-216. [CrossRef]

81. Lowenstein, T.K.; Hardie, L.A.; Timofeeff, M.N.; Demicco, R.V. Secular variation in seawater chemistry and the origin of calcium chloride basinal brines. Geology 2003, 31, 857-860. [CrossRef]

82. Strauss, H. $4 \mathrm{Ga}$ of seawater evolution: Evidence from the sulfur isotopic composition of sulfate. Geol. Soc. Am. Spec. Pap. 2004, 379, 195-205.

83. Kang, Y.; Liu, G.; Chou, C.L.; Wong, M.; Zheng, L.; Ding, R. Arsenic in Chinese coals: Distribution, modes of occurrence, and environmental effects. Sci. Total Environ. 2011, 412-413, 1-13. [CrossRef]

84. Yuzhuang, S.; Cunliang, Z.; Yanheng, L.; Jinxi, W.; Jianya, Z.; Zhe, J.; Mingyue, L.; Kalkreuth, W. Further Information of the Associated Li Deposits in the No.6 Coal Seam at Jungar Coalfield, Inner Mongolia, Northern China. Acta Geol. Sin. 2013, 87, 801-812. [CrossRef] 
85. Dai, S.; Jiang, Y.; Ward, C.R.; Gu, L.; Seredin, V.V.; Liu, H.; Zhou, D.; Wang, X.; Sun, Y.; Zou, J.; et al. Mineralogical and geochemical compositions of the coal in the Guanbanwusu Mine, Inner Mongolia, China: Further evidence for the existence of an $\mathrm{Al}$ (Ga and REE) ore deposit in the Jungar Coalfield. Int. J. Coal Geol. 2012, 98, 10-40. [CrossRef]

86. Zhang, F.; Wang, L. The formation and material sources of the superlarge Hada Gol Ga-bearing coal deposit in Jungar Banner, Inner Mongolia. Geol. China 2009, 36, 417-423.

87. Clauer, N.; Williams, L.B.; Lemarchand, D.; Florian, P.; Honty, M. Illitization decrypted by B and Li isotope geochemistry of nanometer-sized illite crystals from bentonite beds, East Slovak Basin. Chem. Geol. 2018, 477, 177-194. [CrossRef]

88. Greene-Kelly, R. Lithium Absorption by Kaolin Minerals. J. Phys. Chem. 1955, 59, 1151-1152. [CrossRef]

89. Hoyer, M.; Kummer, N.-A.; Merkel, B. Sorption of Lithium on Bentonite, Kaolin and Zeolite. Geosciences 2015, 5, 127-140. [CrossRef]

90. DZ/T 0203-2002. Geology Mineral Industry Standard of P.R. China: Specifications for Rare Metal Mineral Exploration; Geological Press: Beijing, China, 2002. (In Chinese)

Publisher's Note: MDPI stays neutral with regard to jurisdictional claims in published maps and institutional affiliations.

(C) 2020 by the authors. Licensee MDPI, Basel, Switzerland. This article is an open access article distributed under the terms and conditions of the Creative Commons Attribution (CC BY) license (http://creativecommons.org/licenses/by/4.0/). 